\title{
ANALISIS INTENSITAS KEBISINGAN LINGKUNGAN KERJA PADA PEMBANGUNAN TWIN TOWER UIN SUNAN AMPEL SURABAYA
}

\author{
Sarita Oktorina $^{1}$, Bella Sri Aprilia ${ }^{2}$ dan Ikhfany Anjarsari ${ }^{2}$ \\ ${ }^{1}$ Program Studi Teknik Lingkungan, Universitas Islam Negeri Sunan Ampel Surabaya \\ Email: saritaoktorina@gmail.com \\ ${ }^{2}$ Mahasiswa Prodi Teknik Lingkungan, universitas Islam Negeri Sunan Ampel Surabaya \\ Email: newt@ltm.co.id
}

\begin{abstract}
ABSTRAK
Menurut Suma'mur (1996) kebisingan merupakan salah satu faktor bahaya fisik yang sering dijumpai di lingkungan kerja. Menurut Peraturan Menteri Tenaga Kerja dan Transmigrasi Nomor Per.13/Men/X/2011 Tahun 2011 tentang Nilai Ambang Batas Faktor Fisika dan Faktor Kimia di Tempat Kerja, ditetapkan sebesar kurang dari 85 dBA. Kebisingan tidak dapat dipisahkan dari perkembangan industrilisasi karena hampir semua proses produksi di industri akan menimbulkan kebisingan. Penelitian ini dilakukan dengan cara melakukan survey terhadap daerah pembangunan Twin Tower Uin Sunan Ampel Surabaya. Survey dilakukan dengan cara mengukur kebisingan dengan menggunakan sound level meter. Pengukuran di lakukan di beberapa titik pembangunan. Pada tiap titik pengukuran dilakukan empat kali pengukuran. Pada saat pengukuran terdapat hasil yang melebihi nilai ambang batas yaitu sebesar $85,6 \mathrm{~dB}$. Hal ini dikarenakan pada titik tersebut terdapat aktivitas penggalian lubang. Nilai rata-rata terkecil pada area luar gedung yaitu $64,26 \mathrm{~dB}$ sedangkan nilai ratarata terbesar yaitu 78,43 dB. Pada area dalam gedung nilai rata-rata terbesar yaitu $84,23 \mathrm{~dB}$ sedangkan nilai rata-rata terkecil yaitu $66,63 \mathrm{~dB}$. Sehingga jika merujuk pada pengukuran nilai rata-rata, terjadi pencemaran suara pada pembangunan Twin Tower Uin Sunan Ampel Surabaya. Upaya pengendalian kebisingan yang direncanakan adalah dengan pemasangan vibration isolation, partial enclosure, muffler, pengendalian secara administrasi dan pengendalian bising pada pekerja (pemakaian earplug dan earmuff).

Kata kunci: kebisingan, pengendalian kebisingan.
\end{abstract}

\section{PENDAHULUAN}

Kebisingan merupakan gangguan yang dapat mempengaruhi kenyamanan dan kesehatan terutama yang berasal dari kegiatan operasional peralatan pabrik, termasuk pada kegiatan operasional peralatan proyek pembangunan. Menurut Suma'mur (1996) kebisingan merupakan salah satu faktor bahaya fisik yang sering dijumpai di lingkungan kerja. Kebisingan tidak dapat dipisahkan dari perkembangan industrilisasi karena hampir semua proses produksi di industri akan menimbulkan kebisingan. Resiko yang timbul akibat kebisingan dengan tingkat tekanan bunyi diatas nilai ambang batas pendengaran adalah dapat merusak pendengaran atau gangguan pendengaran. Kebisingan juga dapat menyebabkan gangguan yang berpotensi mempengaruhi kenyamanan dan kesehatan terutama berasal dari kegiatan operasional peralatan pabrik, sedangkan operator (karyawan yang mengoperasikan peralatan pabrik) merupakan komponen lingkungan yang terkena pengaruh yang diakibatkan adanya peningkatan kebisingan (Sasongko dkk, 2000). Risiko kerusakan pendengaran (Damage Risk on Hearing) pada karyawan dapat disebabkan oleh paparan bising karena tingkat bising yang tinggi atau waktu kumulatif paparan yang berlebihan. Menurut Peraturan Menteri Tenaga Kerja dan Transmigrasi Nomor Per.13/Men/X/2011 Tahun 2011 tentang Nilai Ambang Batas Faktor Fisika dan Faktor Kimia di Tempat Kerja, ditetapkan sebesar kurang dari $85 \mathrm{dBA}$. Nilai ambang batas kebisingan di tempat kerja adalah intensitas tertinggi dan merupakan nilai rata - rata yang masih dapat di terima tenaga kerja tanpa mengakibatkan hilangnya daya dengar yang tetap, untuk waktu kerja secara terus menerus tidak lebih dari 8 jam sehari dan 40 jam seminggu.

\section{TINJAUAN PUSTAKA}

\section{A. PENGERTIAN KEBISINGAN}

Bunyi merupakan energi berbentuk gelombang yang berasal dari getaran suatu benda yang dapat merambat melalui media baik itu padat, cair, maupun gas, tapi bunyi tidak dapat merambat pada ruang hampa udara. 
Bunyi merupakan energi berbentuk gelombang yang berasal dari getaran suatu benda yang dapat merambat melalui media baik itu padat, cair, maupun gas, tapi bunyi tidak dapat merambat pada ruang hampa udara.

Dalam mempelajari bunyi khususnya yang berkaitan dengan kesehatan pendengaran ada 2 hal yang perlu diketahui :

1.Frekuensi bunyi yang akan menentukan tinggi rendahnya bunyi

2.Amplitudo (simpang getar) yang akan mempengaruhi besar kecilnya (intensitas) bunyi.

Frekuensi yang bisa di dengar manusia antara 20 - 20.000 Hertz (Hz). Bunyi yang kurang dari $20 \mathrm{~Hz}$ disebut dengan Infrasonic, sedangkan lebih dari $20.000 \mathrm{~Hz}$ disebut dengan Ultrasonic.

Proses pendengaran manusia, yaitu :

1.Telinga luar

2.Telinga tengah

3.Telinga dalam

Bising dalam kesehatan kerja, bising diartikan sebagai suara yang dapat menurunkan pendengaran baik secara kwantitatif (peningkatan ambang pendengaran) maupun secara kwalitatif (penyempitan spektrum pendengaran), berkaitan dengan faktor intensitas, frekuensi, durasi dan pola waktu. Kebisingan didefinisikan sebagai "suara yang tak dikehendak, misalnya yang merintangi terdengarnya suara-suara, musik dsb atau yang menyebabkan rasa sakit atau yang menghalangi gaya hidup. Jadi dapat disimpulkan bahwa, kebisingan adalah bunyi atau suara yang tidak dikehendaki dan dapat menggangu kesehatan, kenyamanan serta dapat menimbulkan ketulian.

\section{B. SUMBER - SUMBER KEBISINGAN}

Sumber-sumber bising sangat banyak, namun dikelompokkan menjadi kebisingan industri, kebisingan kegiatan konstruksi, kebisingan kegiatan olahraga dan seni, dan kebisingan lalu lintas.Selanjutnya, emisi kebisingan dipantulkan melalui lantai, atap dan alat-alat.

Sumber bising secara umum ada 2, yaitu :

1.Indoor : manusia, alat-alat rumah tangga dan mesin.

2.Outdoor : lalu lintas, industri dan kegiatan lain.

Pembagian sumber bising yang lain dapat dibedakan menjadi:

1. Sumber terbesar: lalu lintas (darat, laut dan udara)

Tingkat tekanan suara dari lalu lintas dapat diprediksi dari:

a. Kecepatan lalu lintas.

b. Kecepatan kendaraan.

c. Kondisi permukaan jalan.

2. Industri: tergantung kepada jenis industri dan peralatan

a. Mesin-mesin proses, pemotong, penggerinda, blower, kompresor, kipas dan pompa.

b. Sumber terbesarnya abrasi gas pada kecepatan tinggi, fan dan katup ketel uap.

3. Bidang jasa gedung: ventilasi, pembangkit, pendingin ruangan dan pompa pemana.

4. Bidang domestic : kegiatan rumah tangga, vaccum cleaner, mesin cuci dan pemotong rumput.

5. Aktivitas waktu luang : balap mobil, diskotik dan menembak

\section{JENIS - JENIS KEBISINGAN}

Berdasarkan sprektrum frekuensi dan sifat sumber bunyi bising dibagi atas :

1.Bising yang terusmenerus (Continuous/ Steady Noise)

Bising terus menerus dihasilkan oleh mesin yang beroperasi tanpa henti, misalnya blower, pompa, kipas angin, gergaji sirkuler, dapur pijar dan peralatan pemprosesan.Bising terus-menerus adalah bising dimana fluktuasi dari intensitasnya tidak lebih dari $6 \mathrm{~dB}$ dan tidak putus-putus. Bising kontinyu dibagi menjadi 2 (dua) yaitu:

a. Wide Spectrum adalah bising dengan spektrum frekuensi yang luas. Bising ini relatif tetap dalam batas kurang dari $5 \mathrm{~dB}$ untuk periode 0.5 detik berturut-turut, seperti suara kipas angin, suara mesin tenun.

b. Norrow Spectrum adalah bising ini juga relatif tetap, akan tetapi hanya mempunyai frekuensi tertentu saja (frekuensi 500, 1000, 4000) misalnya gergaji sirkuler, katup gas.

2.Bising yang terputus-putus (Intermittent Noise)

Kebisingan saat tingkat kebisingan naik dan turun dengan cepat, seperti lalu lintas dan suara kapal terbang di lapangan udara. Bising jenis ini sering disebut juga intermittent noise, yaitu bising yang 
berlangsung secara tidak terus-menerus, melainkan ada periode relatif tenang, misalnya lalu lintas, kendaraan, kapal terbang, kereta api

3.Bising yang menghentak (Impulsif Noise)

Merupakan kebisingan dengan kejadian yang singkat dan tiba-tiba. Efek awalnya menyebabkan gangguan yang lebih besar, seperti akibat ledakan, misalnya dari mesin pemancang, pukulan, tembakan bedil atau meriam, ledakan dan dari suara tembakan senjata api. Bising jenis ini memiliki perubahan intensitas suara melebihi $40 \mathrm{~dB}$ dalam waktu sangat cepat dan biasanya mengejutkan pendengarnya seperti suara tembakan suara ledakan mercon, meriam.Bising berpola (tones in noise) merupakan bising yang disebabkan oleh ketidakseimbangan atau pengulangan yang ditransmisikan melalui permukaan ke udara. Pola gangguan misalnya disebabkan oleh putaran bagian mesin seperti motor, kipas dan pompa. Pola dapat diidentifikasi secara subjektif dengan mendengarkan atau secara objektif dengan analisis frekuensi.

4.Bising frekuensi rendah (low frequency noise)

Bising ini memiliki energi akustik yang penting dalam range frekuensi 8-100 Hz. Bising jenis ini biasanya dihasilkan oleh mesin diesel besar di kereta api, kapal dan pabrik, bising jenis ini sukar ditutupi dan menyebar dengan mudah ke segala arah dan dapat didengar sejauh bermil-mil.

\section{Bising impulsif berulang}

Berdasarkan pengaruhnya pada manusia, bising dapat dibagi atas :

1. Bising yang mengganggu (Irritating noise). Merupakan bising yang mempunyai intensitas tidak terlalu keras, misalnya mendengkur.

2. Bising yang menutupi (Masking noise)

Merupakan bunyi yang menutupi pendengaran yang jelas, secara tidak langsung bunyi ini akan membahayakan kesehatan dan keselamatan tenaga kerja, karena teriakan atau isyarat tanda bahaya tenggelam dalam bising dari sumber lain.

3. Bising yang merusak (Damaging/Injurious noise)

Merupakan bunyi yang intensitasnya melampaui nilai ambang batas. Bunyi jenis ini akan merusak atau menurunkan fungsi pendengaran.

\section{PENGUKURAN KEBISINGAN}

Untuk mengetahui intensitas kebisingan di lingkungan kerja, digunakan Sound Level Meter. Untuk mengukur nilai ambang batas pendengaran digunakan Audiometer. Untuk menilai tingkat pajanan pekerja lebih tepat digunakan Noise Dose Meter karena pekerja umumnya tidak menetap pada suatu tempat kerja selama 8 jam ketika seseorang bekerja. Nilai ambang intensitas kebisingannya adalah $85 \mathrm{~dB}$ dan waktu bekerjanya maksimum adalah 8 jam per hari.

Sound Level Meter adalah alat pengukur suara. Mekanisme kerja SLM apabila ada benda bergetar, maka akan menyebabkan terjadinya perubahan tekanan udara yang dapat ditangkap oleh alat ini, selanjutnya akan menggerakkan meter petunjuk.

Audiometer adalah alat untuk mengukur nilai ambang pendengaran. Audiometer adalah chart hasil pemeriksaan audiometri. Nilai ambang pendengaran adalah suara yang paling lemah yang masih dapat didengar telinga.

\section{E. PENGARUH KEBISINGAN}

Kebisingan dapat menyebabkan berbagai pengaruh terhadap tenaga kerja, seperti gangguan fisiologis, gangguan psikologis, gangguan komunikasi dan ketulian, atau ada yang menggolongkan gangguan berupa gangguan auditory, misalnya gangguan terhadap pendengaran dan gangguan auditoryseperti komunikasi terganggu, ancaman bahaya keselamatan, menurunkan performance kerja, kelelahan dan stress.

Lebih rinci lagi, maka dapatlah digambarkan dampak kebisingan terhadap kesehatan pekerja sebagai berikut:

1. Gangguan Fisiologis

Pada umumnya, bising bernada tinggi sangat mengganggu, apalagi bila terputus-putus atau yang datangnya tiba-tiba.Gangguan dapat berupa peningkatan tekanan darah $( \pm 10 \mathrm{mmHg})$, peningkatan nadi, konstriksi pembuluh darah perifer terutama pada tangan dan kaki, serta dapat menyebabkan pucat dan gangguan sensoris.

Bising dengan intensitas tinggi dapat menyebabkan pusing/sakit kepala. Hal ini disebabkan bising dapat merangsang situasi reseptor vestibular dalam telinga bagian dalam yang akan menimbulkan efek 
pusing/vertigo. Perasaan mual,susah tidur dan sesak nafas disebabkan oleh rangsangan bising terhadap sistem saraf, keseimbangan organ, kelenjar endokrin, tekanan darah, sistem pencernaan dan keseimbangan elektrolit.

\section{Gangguan Psikologis}

Gangguan psikologis dapat berupa rasa tidak nyaman, kurang konsentrasi, susah tidur dan cepat marah. Bila kebisingan diterima dalam waktu lama dapat menyebabkan penyakit psikosomatik berupa gastritis, jantung, stres, kelelahan dan lain-lain.

\section{Gangguan Komunikasi}

Gangguan komunikasi biasanya disebabkan masking effect (bunyi yang menutupi pendengaran yang kurang jelas) atau gangguan kejelasan suara. Komunikasi pembicaraan harus dilakukan dengan cara berteriak. Gangguan ini menyebabkan terganggunya pekerjaan, sampai pada kemungkinan terjadinya kesalahan karena tidak mendengar isyarat atau tanda bahaya.Gangguan komunikasi ini secara tidak langsung membahayakan keselamatan seseorang.

\section{Gangguan Keseimbangan}

Bising yang sangat tinggi dapat menyebabkan kesan berjalan di ruang angkasa atau melayang, yang dapat menimbulkan gangguan fisiologis berupa kepala pusing (vertigo) atau mual-mual.

\section{Efek pada pendengaran}

Pengaruh utama dari bising pada kesehatan adalah kerusakan pada indera pendengaran yang menyebabkan tuli progresif dan efek ini telah diketahui dan diterima secara umum dari zaman dulu.Mula-mula efek bising pada pendengaran adalah sementara dan pemulihan terjadi secara cepat sesudah pekerjaan di area bising dihentikan. Tetapi apabila bekerja terus-menerus di area bising, maka akan terjadi tuli menetap dan tidak dapat normal kembali, biasanya dimulai pada frekuensi $4000 \mathrm{~Hz}$ dan kemudian makin meluas kefrekuensi sekitarnya dan akhirnya mengenai frekuensi yang biasanya digunakan untuk percakapan.

\section{HASIL}

Pengukuran kebisingan di setiap titik lokasi pembangunan dengan menggunakan Sound Level Meter. Dalam hal ini kita menggunkan sampel layout pasangan dinding bata dan opening lantai 1 fakultas Tarbiyah. Karena setiap bangunan memiliki area yang sama, sehingga dapat djadikan sampel dalam pengukuran.

Berikut adalah hasil pengukuran kebisingan di beberapa titik lokasi proyek pembangunan Twin Tower UIN Sunan Ampel. Sebelum dilakukan pengukuran, terlebih dahulu menentukan titik-titik di setiap area gedung yang akan diukur tingkat kebisingannya. Dalam hal ini ada 8 titik. Terdiri dari 4 titik di area luar gedung (titik 1 sampai titik 4) dan 4 titik di area dalam gedung (titik 5 sampai titik 8). Pada setiap titik di lakukan 3 kali pengukuran, kemudian mengambil nilai rata-rata sebagai nilai akhir.

Tabel 1 Data Pengukuran Kebisingan di Area Pembangunan Gedung Tarbiyah UIN Sunan Ampel Surabaya

\begin{tabular}{|c|c|c|c|c|c|}
\hline $\begin{array}{c}\text { Titik } \\
\text { Pengukuran }\end{array}$ & $\begin{array}{c}\text { Pengukuran 1 } \\
(\mathrm{dB})\end{array}$ & $\begin{array}{c}\text { Pengukuran 2 } \\
(\mathrm{dB})\end{array}$ & $\begin{array}{c}\text { Pengukuran 3 } \\
(\mathrm{dB})\end{array}$ & $\begin{array}{c}\text { Rata-Rata } \\
(\mathrm{dB})\end{array}$ & Pengaruh terhadap Manusia \\
\hline 1 & 74,1 & 85,6 & 75,6 & 78,43 & $\begin{array}{c}\text { Kelelahan mental dan fisik, } \\
\text { psikomatis dan perasaan } \\
\text { jengkel }\end{array}$ \\
\hline 2 & 69,8 & 69,6 & 66,3 & 68,56 & $\begin{array}{c}\text { Kontinu akan berdampak } \\
\text { penyakit jantung }\end{array}$ \\
\hline 3 & 65.9 & 65,7 & 64,7 & 65,43 & $\begin{array}{c}\text { Kontinu akan berdampak } \\
\text { penyakit jantung }\end{array}$ \\
\hline 4 & 64,3 & 64,4 & 64,1 & 64,26 & $\begin{array}{c}\text { Penyempitan pembuluh darah } \\
\text { dan peningkatan frekuensi } \\
\text { denyut jantung }\end{array}$ \\
\hline
\end{tabular}

*Di area luar gedung

Keterangan :

Titik 1 : pada titik ini terdapat aktivitas penggalian lubang dengan alat excavator sehingga nilai yang dihasilkan sebesar 78,43 dB. 
Titik 2 : jarak antara titik kesatu dan kedua sejauh $16 \mathrm{~m}$. Di titik ini masih terpengaruh oleh aktivitas pada titik 1. Nilai yang dihasilkan sebesar 68,56 dB.

Titik 3 : jarak antara titik kedua dan ketiga sejauh $16 \mathrm{~m}$. Di titik ini tidak terdapat aktivitas di luar gedung. Nilai yang dihasilkan sebesar 65,43 dB.

Titik 4 : jarak antara titik ketiga dan keempat sejauh 14,105 m. Di titik ini tidak terdapat aktivitas di luar gedung. Nilai yang dihasilkan sebesar 64,26 dB.

Tabel 2 Data Pengukuran Kebisingan di Area Pembangunan Gedung Tarbiyah UIN Sunan Ampel Surabaya

\begin{tabular}{|c|c|c|c|c|c|}
\hline $\begin{array}{c}\text { Titik } \\
\text { Pengukuran }\end{array}$ & $\begin{array}{c}\text { Pengukuran 1 } \\
(\mathrm{dB})\end{array}$ & $\begin{array}{c}\text { Pengukuran 2 } \\
(\mathrm{dB})\end{array}$ & $\begin{array}{c}\text { Pengukuran 3 } \\
(\mathrm{dB})\end{array}$ & $\begin{array}{c}\text { Rata-Rata } \\
(\mathrm{dB})\end{array}$ & Pengaruh terhadap Manusia \\
\hline 5 & 84,4 & 84,2 & 84,1 & 84,23 & $\begin{array}{c}\text { Kerusakan alat pendengaran dan } \\
\text { penurunan daya pendengaran }\end{array}$ \\
\hline 6 & 68,9 & 82,9 & 82,9 & 78,23 & $\begin{array}{c}\text { Kelelahan mental dan fisik, } \\
\text { psikomatis dan perasaan jengkel }\end{array}$ \\
\hline 7 & 69,1 & 73,2 & 71,2 & 71,16 & $\begin{array}{c}\text { Kelelahan mental dan fisik, } \\
\text { psikomatis dan perasaan jengkel }\end{array}$ \\
\hline 8 & 68,0 & 69,2 & 62,7 & 66,63 & $\begin{array}{c}\text { Kontinu akan berdampak } \\
\text { penyakit jantung }\end{array}$ \\
\hline
\end{tabular}

*Di area dalam gedung

Keterangan :

Titik 5 : di titik ini terdapat aktivitas pemotongan besi. Sehingga nilai yang dihasilkan 84,23 dB.

Titik 6 : jarak antara titik kelima dan keenam sejauh $16 \mathrm{~m}$, di titik ini masih terpengaruh aktivitas pada titik 5. Nilai yang dihasilkan sebesar 78,23 dB.

Titik 7 : jarak antara titik keenam dan ketujuh sejauh 16 m, di titik ini terjadi aktivitas memalu. Sehingga nilai yang dihasilkan sebesar $71,16 \mathrm{~dB}$.

Titik 8 : jarak antara titik ketujuh dan kelapan sejauh $16 \mathrm{~m}$, di titik ini terjadi pengeboran dinding. Sehingga nilai yang dihasilkan sebesar 66,63 dB.

\section{KESIMPULAN}

Dari hasil observasi yang telah dilakukan di dapatkan hasil pengaruh kebisingan terhadap pembangunan gedung Twin Towers UIN Sunan Ampel Surabaya memang menghasilkan suatu pencemaran yaitu pencemaran suara. Sumber pencemaran tersebut berasal dari beberapa peralatan yang digunakan dalam pembangunan gedung Twin Towers, seperti Excavator yang digunakan untuk penggalian lubang, geranda yang digunakan untuk menggergaji suatu bahan bangunan, bor untuk melubangi suatu bahan bangunan dan lain sebagainya. Melalui sumber pencemaran tersebut, menghasilkan tingkat kebisingan kategori terganggu, dimana tingkat kebisingan tidak terjadi dalam perhitungan satu waktu dan tempat kerja atau kegiatan yang dilakukan sama. Dan kategori tingkat kebisingan terpapar jika dalam perhitungan satu waktu dan tempat kerja atau kegiatan yang dilakukan sama. Sehingga, para pekerja diharuskan untuk menggunakan alat pelindung telinga (earplug) untuk mencegah tingkat kebisingan yang terlalu berat.

\section{DAFTAR PUSTAKA}

Barnes, Ralph M. 1980. Motion and Time Study Design and Measurement of Work. SeventhEdition. Canada: John Wiley \& Sons, Inc.

Cohran, William G. 2005. Teknik Penarikan Sampel.Edisi Ketiga. Jakarta: UI-Press.

Department of Labor. Salvendy, Gabriel. 1997. Human Factors and Ergonomics. Second Edition. Canada: John Wiley \& Sons Inc.

Defi, P., Inafalia, I, 2005.Monitoring Kualitas Lingkungan Kerja di Billet Steel Plant PT. Krakatau Steel. Jurusan Teknik Lingkungan, Universitas Andalas. Padang.

Depnakertrans RI. 2011. Permenakertrans No. 13/Th.2011 tentang Nilai Ambang Batas Faktor Fisika Dan Faktor Kimia Di Tempat Kerja. Depnakertrans RI. Jakarta, Indonesia.

Goembira, Bachtiar, V,S., Diktat Mata Kuliah Pengendalian Bising, 2003, Jurusan Teknik Lingkungan, Universitas Andalas. Padang, Indonesia.

Huboyo, Haryono Setiyo. 2008. Analisis Sebaran Kebisingan Fasilitas Utility PT. Pertamina (Persero) UP-VI Balongan Indramayu. Semarang: UNDIP.

Keputusan Menteri Negara Lingkungan Hidup No. 48 Tahun 1996 Tentang: Baku Tingkat Kebisingan. Jakarta. 
Keputusan Menteri Negara Tenaga Kerja No. KEP51/MEN/1999. Nilai Ambang Batas Faktor Fisika di Tempat Kerja. Jakarta.

Khairansyah, M. D., Natalia, D., Priyatmono, A.2011, Laporan Resmi Praktikum Lingkungan Kerja. PPNS-ITS, Surabaya, Indonesia.

Mangunwijaya, Y. B. 1994. Pengantar Fisika Bangunan. Jakarta: Djambatan.

Marras, William, dkk. 2006. Fundamentals and Assessment Tools for Occupational Ergonomics. USA:

Taylot \&Francais Group CRC Press. OSHA. 1980. Noise Control, A Guide for Workers and Employers. Washington: U.S.

Saenz, A. Lara, dkk. 1986. Noise Pollution (Editing). Paris: ICSU\&SCOPE

Sevilla, Consula G, dkk. 1991. An Introduction to Research Methods. Philippines: Rex Printing Company

Wald, H., dkk. 2002. Physical and Biological Hazard of The Workplace, Second Edition. Canada: John Wiley \& Sons, Inc. 